\title{
Comparative evaluation of different reference evapotranspiration models
}

\author{
C. K. Arya ${ }^{1 *}$, R. C. Purohit ${ }^{2}$, L. K. Dashora ${ }^{1}$, P. K. Singh ${ }^{2}$, Mahesh Kothari ${ }^{2}$ and Bhim Singh ${ }^{1}$ \\ ${ }^{1}$ College of Horticulture and Forestry, Agriculture University, Kota, Jhalawar-326023 (Rajasthan), INDIA \\ ${ }^{2}$ Department of Soil and Water Engineering, College of Technology and Engineering, Maharana Pratap University \\ of Agriculture and Technology, Udaipur-313001 (Rajasthan), INDIA \\ *Corresponding author. E-mail: er_ckarya@yahoo.com
}

Received: May 31, 2016; Revised received: January 25, 2017; Accepted: February 24, 2017

\begin{abstract}
The study was carried out to select best alternative method for the estimation of reference evapotranspiration $\left(E T_{0}\right)$. Accurate estimation of potential evapotranspiration is a necessary step in water resource management. Recently, the FAO-56 version of Penman-Monteith equation has been established as a standard for calculating reference evapotranspiration ( $\left.\mathrm{ET}_{0}\right)$ which requires measurement of a number of meteorological parameters namely, air temperature, relative humidity, solar radiation, and wind speed which may not be available in most of the meteorological stations. Still there are different approaches (requiring less data) which estimate $\mathrm{ET}_{0}$ closely to PenmanMonteith (P-M) method for different climatological conditions. The present study is based on analysis of long term of 13 years (2000 to 2012) climatic data to calculate monthly reference evapotranspiration for Capsicum production (September-March) and also to compare the performance of evapotranspiration equations for Jhalawar district of Rajasthan with the standard FAO-56 Penman-Monteith method on the basis of the least root mean square error (RMSE) analysis. Hargreaves method and Pan evaporation (E-Pan) method overestimated the values of ETo when compared with FAO-56 Penman-Monteith method. On the basis of lowest value of RMSE, Pan evaporation method is found best alternative method to FAO-56 Penman-Monteith method in the study area.
\end{abstract}

Keywords: CROPWAT, Hargreaves and Pan evaporation, Reference evapotranspiration, RMSE analysis

\section{INTRODUCTION}

Allen et al. (1994) defined reference evapotranspiration $\left(\mathrm{ET}_{0}\right)$ as "the rate of evapotranspiration from a hypothetical reference crop with an assumed crop height of $0.12 \mathrm{~m}$, a fixed surface resistance of $70 \mathrm{~s} \mathrm{~m}^{-1}$ and an albedo of 0.23 closely resembling the evapotranspiration from an extensive surface of green grass of uniform height actively growing completely shading the ground and with adequate water. The combination of two processes i.e. evaporation and transpiration is called Evapotranspiration. Evaporation is the process where by liquid water is converted to water vapour and removed from evaporative surface. Transpiration consists of the vaporization of liquid water contained in plant tissues and vapour removal to the atmosphere. Evaporation and transpiration occur simultaneously and there is no way to distinguish between the two processes. The most common and important factors affecting evaporation are solar radiation, temperature, relative humidity, vapour pressure deficit, atmospheric pressure, and wind (Kumar et al., 2013). Evapotranspiration not only plays a major role in global water balance but also significantly influence the global energy balance (Nikam et al., 2014). Evapotranspiration is one of the most important and complicated phases of the hydrological cycle. Hence, quantification of evapotran- spiration is necessary for water resources management, irrigation scheduling and environmental assessment, design of reservoirs, irrigation systems, water balance and simulations studies Jensen et al. (1990). Several methods have been developed to assess $\mathrm{ET}_{0}$ based on temperature, radiation and their combination. Performance evaluation of all the approaches is prerequisite for selecting an alternative approach in accordance with available data. Solar radiation provides the energy required for the phase change of water and often limits the evapotranspiration (ET) process where water is readily available. A number of ET equation methods have been developed based on energy balance (Turc, 1961; Priestley and Taylor, 1972; Doorenbos and Pruitt, 1977). Jensen et al. (1990) found that radiation methods considerably underestimated evapotranspiration for rates greater than $4 \mathrm{~mm} /$ day. George et al. (2002) have developed decision support system for estimating reference evapotranspiration using temperature, radiation and combination methods. Specific devices and accurate measurements of various physical parameters of the soil water balance in lysimeters are required to measure actual evapotranspiration. These methods are often expensive and require accuracy for measurements. Direct methods are inappropriate for routine measurements. It is important to evaluate the $\mathrm{ET}_{0}$ estimated by indirect methods. Due to simplicity 
in indirect methods, weather parameters are used for estimation of $\mathrm{ET}_{0}$ (Meshram et al., 2011). In search of the best $\mathrm{ET}_{0}$ model for global application, many researchers (Allen et al., 1998; Villa Nova et al., 2007) have compared different reference evapotranspiration models. Sikka et al. (2001); Kar and Martha (2006) and Meshram et al. (2010) have provided the detail reviews on the comparison of different models and concluded The Penman-Monteith model is the most appropriate for determining $\mathrm{ET}_{0}$.

Owing to its superiority tested worldwide the "physically based" combination approach of FAO-56 version of Penman-Monteith (FAO-PM) equation has been accepted as a standard for calculating reference evapotranspiration. Superior accuracy of FAO-56 Penman-Monteith methods is also verified in Indian conditions by Kashyap and Panda (2001). Viswanadh et al. (2004) developed a computer program in Microsoft Visual $\mathrm{C}^{++}$which is generalized to calculate reference evapotranspiration (RET) using FAO-56 PM method. This program is based on the FAO-56 Penman-Monteith equation as given by FAO irrigation and Drainage Paper No.56 (Allen et al. 1988). Giridhar et al. (2004) compared $\mathrm{ET}_{0}$ values estimated through various $\mathrm{ET}_{0}$ equations with FAO-56 PM method for different irrigation project locations in Andhra Pradesh. Lakshman and Gicy (2006) studied the performance of various $\mathrm{ET}_{0}$ equations and concluded that there is growing evidence to show that the more physically based FAO-56 Penman-Monteith (PM) combination method yields consistently more accurate $\mathrm{ET}_{0}$ estimates across a wide range of climates. Rahimikhoob et al. (2012) evaluated the performance and characteristic behaviour of four equations for estimating reference evapotranspiration $\left(\mathrm{ET}_{0}\right)$ at eight meteorological sites in a subtropical climate and concluded that good performance from the modified Hargreaves (equation $\left(0.53 \mathrm{~mm} \mathrm{~d}^{-1}\right.$ of RMSE) must be emphasized, given the simplicity of that method, which only requires maximum and minimum air temperature data.

The objectives of the present study to select best alternative method for the estimation of daily and monthly reference evapotranspiration $\left(\mathrm{ET}_{0}\right)$ for Jhalawar district (Rajasthan), India. Therefore, two most popular approaches Hargreaves and Pan evaporation based on very less number of meteorological data, were used to estimate daily and monthly reference evapotranspiration $\left(\mathrm{ET}_{0}\right)$ compare the performance of these equations with FAO-56 Penman-Monteith method.

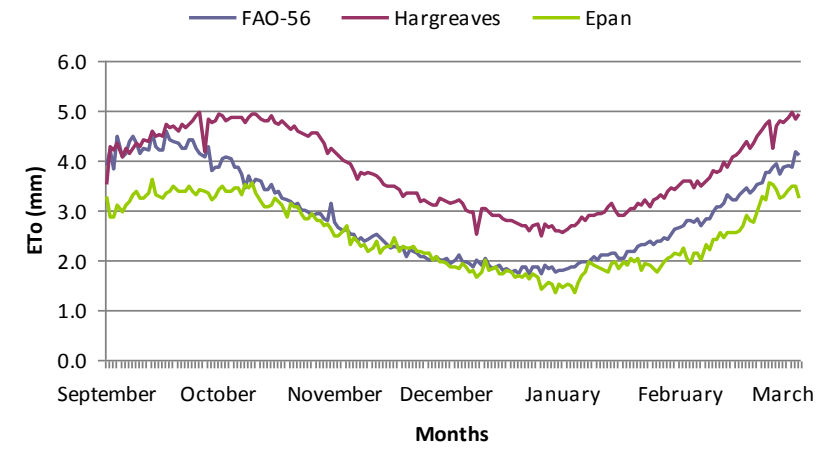

Fig 1. Estimated reference evapotranspiration, $E T_{0}(\mathrm{~mm})$ by different methods.

\section{MATERIALS AND METHODS}

Study area: Jhalawar district is located at $23^{\circ} 45^{\prime}$ to $24^{\circ} 52^{\prime}$ N-Latitude and $75^{\circ} 27^{\prime}$ to $76^{\circ} 56^{\prime}$ E-Longitude in south eastern Rajasthan. Agro-climatically, the district falls in Zone V, known as Humid South Eastern Plain. The rainfall is mostly concentrated in four monsoon months of June to September besides some regeneration in the winter months. On the basis of available rainfall data, the average annual rainfall in the study area is $910 \mathrm{~mm}$ (Singh, 2016). Maximum temperature range in the summer is $43-48^{\circ} \mathrm{C}$ and minimum 1.0-2.6 ${ }^{\circ} \mathrm{C}$ during winter. The district is having conspicuous physiographic variations comprising undulating or flat terrain. About 78.5 percent population of the district is rural whose main occupation is agriculture (Anonymous, 2011).

Meteorological parameters viz., maximum temperature, minimum temperature, minimum relative humidity, maximum relative humidity, wind speed, sun shine duration were collected from CSWCRTI, Kota and analysed for capsicum (Capsicum annuum L.var. grossum), popularly known as sweet pepper, capsicum and shimla mirch (September-March) for a period of 2000 to 2012. In the present study, the same method was chosen as the standard method against which performance evaluation of the other methods was carried out. The average monthly $\mathrm{ET}_{0}$ were calculated on the basis of meteorological data. The $\mathrm{ET}_{0}$ values estimated from Hargreaves methods and Pan evaporation method were compared with the standard method i.e., FAO-56 PM on the basis of the least root mean square error (RMSE) analysis. RMSE provides a good measure of how closely the datasets match (Ventura et al., 1999).

Table 1. Average monthly meteorological data during crop growing period during (2000-2012) for the study area.

\begin{tabular}{lllllll}
\hline Month & Min Temp $\left({ }^{\circ} \mathbf{C}\right)$ & Max Temp $\left({ }^{\circ} \mathbf{C}\right)$ & Humidity $(\%)$ & Wind $(\mathbf{k m} / \mathbf{h r})$ & Sun Hours & Ep \\
\hline September & 23.8 & 33.5 & 70 & 2.1 & 7.9 & 4.4 \\
October & 17.9 & 34.7 & 54.68 & 1.1 & 9.4 & 4.3 \\
November & 12.71 & 30.45 & 58 & 0.94 & 8.3 & 3.2 \\
December & 8.69 & 25.36 & 64.74 & 1 & 7.6 & 2.4 \\
January & 6.54 & 23.09 & 64.43 & 1.4 & 7.9 & 2.3 \\
February & 9.59 & 26.84 & 59.2 & 1.9 & 9.1 & 3.2 \\
March & 13.2 & 31.2 & 49.1 & 2.8 & 9.7 & 3.8 \\
\hline
\end{tabular}


Table 2. Average monthly reference evapotranspiration $\left(\mathrm{ET}_{0}\right)$ in mm estimated by different methods (2000-2012).

\begin{tabular}{lccc}
\hline \hline Months & P-M & Hargreaves & $\mathbf{E}_{\text {pan }}$ \\
\hline September & 128.23 & 130.42 & 130.81 \\
October & 110.31 & 147.38 & 133.3 \\
November & 73.8 & 111.98 & 95.3 \\
December & 59.03 & 93.79 & 74.6 \\
January & 63.51 & 89.82 & 72.22 \\
February & 83.12 & 106.6 & 88.92 \\
March & 137.19 & 168.38 & 170.1 \\
\hline
\end{tabular}

Table 3. Monthly root mean square error (RMSE) over Penman-Monteith method (2000-2012).

\begin{tabular}{lcc}
\hline \multirow{2}{*}{ Parameter } & \multicolumn{2}{c}{ Methods } \\
\cline { 2 - 3 } & Hargreaves & $\mathbf{E}_{\text {pan }}$ \\
\hline RMSE (mm/Month) & 29.908 & 18.641 \\
\hline
\end{tabular}

The RMSE was calculated by using the equation (1)

$$
R M S E=\sqrt{\frac{1}{n} \sum\left(E T o_{1}-E T o_{2}\right)^{2}}
$$

Where,

$\mathrm{n} \quad=$ Number of observations

$\mathrm{ETo}_{1}=$ Estimated ETo, by P-M method

$\mathrm{ETo}_{2}=$ Estimated ETo, by one of two methods

FAO-56 penman-monteith equation: The definition of $\mathrm{ET}_{0}$ by Allen et al. (1994) was the basis for FAO Penman-Monteith method in the estimation of Reference Evapotranspiration. The FAO-56 PM is a physically based approach that requires measurements of a number of meteorological parameters. Biswas et al., (2014) computed actual crop evapotranspiration $\left(\mathrm{ET}_{0}\right)$ by multiplying the reference evapotranspiration $\left(\mathrm{ET}_{0}\right)$ with crop coefficient $\left(\mathrm{K}_{\mathrm{c}}\right)$ for different growth stages of the crop. The monthly reference evapotranspiration $\left(\mathrm{ET}_{0}\right)$ was estimated by using the 'CROPWAT 8.0' Model based on FAO Penman-Monteith (Allen et al., 1998) method from the available data of temperature, relative humidity, wind speed at $2 \mathrm{~m}$ height and sunshine hours.

The FAO Penman-Monteith method to estimate reference crop evapotranspiration is as follows

$$
E T_{o}=\frac{0.408 \Delta\left(R_{n}-G\right)+\gamma \frac{900}{T+273} U_{2}\left(e_{s}-e_{a}\right)}{\Delta+\gamma\left(1+0.34 U_{2}\right)}
$$

Where,

$\mathrm{ET}_{0}=$ reference evapotranspiration $\left[\mathrm{mm} \mathrm{day}^{-1}\right], \mathrm{R}_{\mathrm{n}}$ net radiation at the crop surface $\left[\mathrm{MJ} \mathrm{m}^{-2}\right.$ day $\left.^{-1}\right], \mathrm{G}$ soil heat flux density $\left[\mathrm{MJ} \mathrm{m}^{-2}\right.$ day $\left.^{-1}\right]$, T mean daily air temperature at $2 \mathrm{~m}$ height $\left[{ }^{\circ} \mathrm{C}\right], \mathrm{u}_{2}$ wind speed at $2 \mathrm{~m}$ height $[\mathrm{m}$ $\left.\mathrm{s}^{-1}\right]$, $\mathrm{e}_{\mathrm{s}}$ saturation vapour pressure $[\mathrm{kPa}], \mathrm{e}_{\mathrm{a}}$ actual vapour pressure $[\mathrm{kPa}], \mathrm{e}_{\mathrm{s}}-\mathrm{e}_{\mathrm{a}}$ saturation vapour pressure deficit $[\mathrm{kPa}]$.

Hargreaves method: The Hargreaves method (Hargreaves and Samani, 1985) of computing daily reference evapotranspiration is another empirical approach that was used in cases where the availability of weather data is limited. The method was developed in Davis, California from a lysimeter study on Alta fescue grass. This is an empirical estimation method that uses the average daily air temperature, $\mathrm{T}\left({ }^{\circ} \mathrm{C}\right)$, in combination with the extraterrestrial radiation, $\mathrm{Ra}(\mathrm{MJ} / \mathrm{m} 2 /$ day) as an indicator of the incoming global radiation. Hargreaves equation can be written as:

$$
E T_{o}=0.0135 R_{s}\left(T_{a}+17.8\right)
$$

Where,

$\mathrm{R}_{\mathrm{s}}=$ Global solar radiation $(\mathrm{mm} /$ day $)$

$\mathrm{T}_{\mathrm{a}}=$ daily average temperature ${ }^{0} \mathrm{C}$

$$
R_{s}=k_{r} R_{a}\left(T_{\max }-T_{\min }\right)^{0.5}
$$

Where,

$\mathrm{R}_{\mathrm{a}}=$ extraterrestrial radiation ( $\mathrm{mm} /$ day)

$\mathrm{k}_{\mathrm{r}}=$ empirical coefficient depending on station location Hargreaves (1994) recommended using $\mathrm{K}_{\mathrm{r}}=0.162$ for "interior" regions and $\mathrm{K}_{\mathrm{r}}=0.19$ for coastal regions.

$$
\mathrm{Ra}=\frac{24 * 60}{\Pi} \mathrm{Gsc} * d r[\omega \mathrm{S} \operatorname{Sin}(\phi) \operatorname{Sin}(\delta)+\operatorname{Cos}(\phi) \operatorname{Cos}(\delta) \operatorname{Sin}(\omega \mathrm{s})]
$$

Where, Ra-extraterrestrial radiation [MJm-2day-1], Gsc-solar constant $=0.0820 \mathrm{MJm}-2 \mathrm{~min}-1, \mathrm{dr}$-inverse relative distance Earth-Sun, $\omega$ s -sunset hour angle [rad], $\phi$ - latitude [rad], $\delta$ - solar declination [rad]. The latitude, $\phi$, expressed in radians is positive for the northern hemisphere and negative for the southern hemisphere.

$$
\begin{aligned}
& d r=1+0.033 \operatorname{Cos}\left[\frac{2 \pi}{365} J\right] \\
& \delta=0.409 \operatorname{Sin}\left[\frac{2 \pi}{365} J-1.39\right] \\
& \omega s=\operatorname{arcCos}[-\tan \phi * \tan \delta]
\end{aligned}
$$

Pan evaporation method: The Standard US Weather Bureau Class A pan was used to measure evaporation data in the field. Evaporation pans have higher rates of evaporation than a large free water surface, and a factor is usually recommended for converting the observed evaporation rate to those of large water surface areas. This factor is called pan coefficient. Reference evapo-transpiration was calculated by multiplying pan evaporation data $\left(\mathrm{E}_{\mathrm{pan}}\right)$ to pan coefficient $\left(\mathrm{K}_{\mathrm{p}}\right)$.

$$
E T_{o}=K_{p} E_{p a n}
$$

Where, ETo $=$ Reference crop evapo-transpiration (mm/month)

$\mathrm{K}_{\mathrm{p}}=$ Pan coefficient

$\mathrm{E}_{\mathrm{pan}}=$ pan evaporation $(\mathrm{mm} / \mathrm{month})$

\section{RESULTS AND DISCUSSION}

P-M method was accepted as the most appropriate method for estimation of $\mathrm{ET}_{0}$ and compared with other 
two methods. Monthly $\mathrm{ET}_{0}$ were calculated on the basis of meteorological data for growing period (September to March) of Capsicum using the FAO-56 Penman-Monteith, Hargreaves Method and Pan evaporation method (Table 2 and Fig. 1). It is reveled from Fig. 1 that $\mathrm{ET}_{0}$ values estimated by Hargreaves Method are the highest followed by Pan evaporation and P$\mathrm{M}$ methods. Hargreaves method was found to be the most suitable method for the Manipur region with least biasness and minimum error by Naorem and Devi (2014). Giridhar et al. (2004) estimated reference evapotranspiration values from Hargreaves method, Turc method, FAO-24 Radiation method and resulted in positive percentage of deviation as $26.68 \%, 10.63$ $\%$ and $42.69 \%$ respectively when compared with FAO -56 Penman-Monteith method. Turc (1961) equation gave $10.63 \%$ deviation from FAO-56 PM method and the deviation is found to be least among all the radiation methods for Andhra Pradesh, India. Lima et al., (2013) estimated Reference evapotranspiration by noncalibrated Hargreaves-Samani method $\left(\mathrm{ET}_{0} \mathrm{HS}\right)$ which was overestimated in all months (RMSE $=1.43 \mathrm{~mm} /$ day) in sub-humid region of Brazil.

The monthly values of RMSE were calculated to compare other two methods with P-M method and presented in Table 3. It was observed from Tables 3 that Pan evaporation method gave the RMSE values (18.641 $\mathrm{mm} / \mathrm{month}$ ) closest to the P-M method followed by Hargreaves ( $29.908 \mathrm{~mm} / \mathrm{month}$ ). Hargreaves overestimated due to high difference in temperatures $\left(\mathrm{T}_{\max }\right.$ $\mathrm{T}_{\min }$ ) values. Hence, Pan evaporation method is recommended for the estimation of $\mathrm{ET}_{0}$ in the absence of data required for estimation of $\mathrm{ET}_{0}$ by $\mathrm{P}-\mathrm{M}$ method for Jhalawar district of Rajasthan.

\section{Conclusion}

As the FAO-56 version of Penman-Monteith equation has been established as a standard for calculating reference evapotranspiration $\left(\mathrm{ET}_{0}\right)$ which requires measurements of a number of meteorological parameters. This study reveals that Pan evaporation approach showed lowest values of RMSE (18.641 mm/month) for both daily and monthly $\mathrm{ET}_{0}$ values as compare to Hargreaves Samani equation. It is concluded from the comparison that Pan evaporation approach is the best alternative to $\mathrm{P}-\mathrm{M}$ method to estimate $\mathrm{ET}_{0}$ values in the Jhalawar district of Rajasthan.

\section{REFERENCES}

Allen, R.G., Smith, M., Perrier, A. and Pereira, L.S. (1994). An update for the definition of reference evapotranspiration. ICID Bulletin, 43(2): 1-34.

Allen, R.G., Periera, L.S., Raes, D. and Smith, M. (1998). Crop evapotranspiration: Guidelines for computing crop requirements, Irrigation and Drainage, Paper No. 56, FAO, Rome, Italy Pp. 300.

Anonymous (2011). District Census Handbook, Jhalawar Rajasthan. Census of India 2011, Series-09, Part XII-B,
Pp. 13.

Biswas, S.K., Akanda, A.R., Rahman, M.S. and Hossain, M. A. (2014). Effect of drip irrigation and mulching on yield, water-use efficiency and economics of tomato. Plant Soil and Environment, 61(3): 97-102.

Doorenbos, J. and Pruitt, W. O. (1977). Guidelines to crop water requirements. Irrigation and Drainage, Paper No. 24 (revised), FAO, Rome, Italy Pp. 144.

George, B.A., Reddy, B.R.S., Raghuswamy, N.S. and Wallender, W. (2002). Decision support system for estimating reference evapotranspiration, Journal of Irrigation and Drainage Engineering, 128(1):1-10

Giridhar, M.V.S.S., Viswnadh G.K. and Kanaka Durga P. (2004). Comparison of reference evapotranspiration equations in Andhra Pradesh, India. Proceedings of international conference at Omaha, Nebraska, U.S.A., organized by ASCE, EWRI, during $21^{\text {st }}-25^{\text {th }}$ March 2006.

Hargreaves, G. H. (1994). Simplified coefficients for estimating monthly solar radiation in North America and Europe. Departmental Paper, Dept. of Biol. And Irrig. Engrg., Utah State University, Logan, Utah.

Hargreaves, G.H. and Samani, Z.A. (1985). Reference crop evapotranspiration from temperature, Applied Engineering in Agriculture, 1(2): 96-99

Jensen, M.E ., Burman, R.D. and Allen, R.G. (1990). Evapotranspiration and irrigation water requirements. ASCE Manuals and Reports on Engineering Practices No.70., ASCE, New York Pp. 360.

Kar, G. and Martha, M. (2006). Development of software for computing reference crop evapotranspiraton for water management. Indian Journal of Soil Conservation, 34 (2):161-163

Kashyap, P.S. and Panda, R.K. (2001). Evaluation of evapotranspiration estimation methods and development of crop-coefficients for potato crop in sub-humid region. Agricultural Water Management, 50:9-25

Kumar, P., Rasul, G. and Kumar, D. (2013). Evaporation Estimation from Climatic Factors. Pakistan Journal of Meteorology, 9(18): 51-57

Lakshman, N. and Gicy M. K. (2006). Performance evaluation of reference evapotranspiration equations across a range of Indian conditions. Journal of Irrigation and Drainage Engineering, 132(3): 238-249

Lima, J., Antonino, A., Souza, E., Hammecker, C., Montenegro, S. and Lira, C. (2013). Calibration of HargreavesSamani equation for estimating reference evapotranspiration in sub-humid region of Brazil. Journal of Water Resource and Protection, 5(12A): 1-5

Meshram, D.T., Gorantiwar, S.D., Mittal, H.K. and Purohit, R.C. (2010). Reference crop evapotranspiration studies in the Pomegranate growing district (Ahmednagar) of western part of Maharashtra state. Indian Journal of Soil Conservation, 38(2): 80-85

Meshram, D. T., Gorantiwar, S. D., Jadhav, V. T. and Ram Chandra (2011). Evaluation of ET models to study water requirement of Pomegranate (Punica granatum L.) for Satara district of Maharashtra. Indian Journal of Soil Conservation, 39(2): 142-148

Nikam, B.R., Kumar, P., Garg, V., Thakur, P.K. and Aggarwal, S.P. (2014). Comparative evaluation of different potential evapotranspiration estimation approaches. International Journal of Research in Engineering and Technology, 3(6): 544-552 
Naorem, N. and Devi, T.K. (2014). Estimation of potential evapotranspiration using empirical models for Imphal. International Journal of Innovative Technology and Exploring Engineering (IJITEE), 4(7): 119-123

Priestley, C.H.B. and Taylor, R.J. (1972). On assessment of surface heat flux and evaporation using large scale parameters, Monthly Weather Review, 100: 81-92

Rahimikhoob, A., Behbahani, M. R. and Fakheri, J. (2012). An evaluation of four reference evapotranspiration models in a subtropical climate. Water Resources Management, 26(10): 2867-2881

Sikka, A. K., Maddu, M. and Tripathi, K. P. (2001). Comparison of different methods of estimating evapotranspiration in Nilgiris, South India. Indian Journals of Soil Conservation, 29(3): 213-219

Singh, B. (2016). Rainfall variability and drought analysis of Jhalawar district of Rajasthan, India. Journal of Applied and Natural Science, 8 (1): 116-121
Turc, L. (1961). Estimation of irrigation water requirements, potential evapotranspiration: A simple climatic formula evolved up to date. Journal of Annales Agronomiques, 12:13-14

Ventura, F.D., Spano, P.D. and Snyder, R.L. (1999). An evaluation of common evapotranspiration equation. Irrigation Science, 18: 163-170

Villa Nova, N. A., Pereira, A. B. and Shock, C.C. (2007). Estimation of reference evapotranspiration by an energy Balance approach. Biosystems Engineering, 96(4):605615

Viswanadh, G.K., Giridhar, M.V.S.S. and Kanaka Durga P. (2004). Estimation of reference crop evapotranspiration by developing software-application to a sub basin of the river Krishna, India, Proc. of the International Conference during $18^{\text {th }}-20^{\text {th }}$ December 2006, organized by American Society of Civil Engineers (ASCE), IIT, Kanpur, at IIT, Delhi, India. 